\title{
PIWO I GOSPODA W KULTURZE CZESKIEJ - POLSKIE WIDZENIE ZJAWISKA
}

WPROWADZENIE

$\mathrm{P}$

rzynajmniej na trzy sposoby można uzasadnić podejmowanie rozważań na temat zasygnalizowany $w$ tytule. Po pierwsze, chodzi o to, że kwestie związane z alkoholem czy też czymś, co można by nazwać „kulturą biesiady”, w Polsce z reguły są przedmiotem szeroko rozumianych studiów kulturoznawczych (np. prace Rocha Sulimy), niniejszy artykut w założeniu autora ma charakter socjologiczny. Pewne znaczenie ma tu również okoliczność, że w szerszym obiegu tego typu tematyka najczęściej jest postrzegana albo przez pryzmat „niskiej” formy rozrywki, czasami na dodatek skutkującej nieprzyjemnym dla otoczenia zachowaniem ze strony tych, którzy uczestniczyli we wzmożonej konsumpcji alkoholu, albo jest przedmiotem wnikliwych obserwacji ze strony osób zajmujących się stadium krańcowym - nałogiem. Pomiędzy tymi biegunami pozostaje zaś to, na czym postanowiono skoncentrować się w prezentowanym artykule: cała rozległa sfera, której częścią są społeczno-kulturowe aspekty funkcjonowania gospód bądź piwiarni.

Po drugie, zarysowanej powyżej problematyce towarzyszy istotne zastrzeżenie, że rzecz całą należy odnieść do kontekstu czeskiego. To zaś oznacza, że zneutralizowania wymagają niektóre komponenty stereotypu Czecha w oczach Polaka, sprawiające, iż podjęty temat może jawić się jako mało interesujący czy wręcz niepoważny. Czymże bowiem jest w stanie zaskoczyć Polaka „śmieszny Czech, mówiący śmiesznym językiem" - jak głosi jeden z powszechniejszych na jego temat polskich stereotypów - potrafiący niemalże

Dr Marcin DĘBICKI jest adiunktem w Zakładzie Socjologii Pogranicza Instytutu Socjologii na Uniwersytecie Wrocławskim. md4@wp.pl 
medytować (bywa, że w samotności) nad kuflem piwa, a w czym trudno jest dostrzec jakieś emocje czy wyrafinowanie? Łączy się to z inną kliszą, niekiedy zresztą podtrzymywaną przez obcokrajowców - że Polacy potrafią się „dobrze bawić” oraz że mają oni duże możliwości co do konsumpcji alkoholu. Ten zaś punkt może zostać wzmocniony opinią - skądinąd prawdziwą - że czeskie piwo jest raczej słabsze od polskiego (przez co należy rozumieć to, iż zawiera ono mniej alkoholu). To z kolei mogłoby sprzyjać dodatkowej deprecjacji „czeskich nawyków biesiadnych”, bo przecież - może pomyśleć niejeden Polak - jak można się dobrze bawić przy piwie (tylko piwie), i to słabym? Toż ile trzeba by go wypić, aby "osiągnąć efekt"?

Po trzecie, niniejsze rozważania dotyczą specyficznego z polskiego punktu widzenia typu obiektów, jakim są wiejskie lub małomiasteczkowe hospody czy hostince w Republice Czeskiej. Chociaż w kulturze ziem byłej Korony Świętego Wacława mają one swoją niebagatelną tradycję, to jednak na przybyszach znad Wisły mogą - przynajmniej początkowo - wywrzeć nie najlepsze wrażenie. Ograniczenie przytoczonych tu obserwacji do tego typu lokali wynika z przeświadczenia, że wielkomiejskie restauracje - nie mówiąc już o klubach, pubach czy dyskotekach (także najczęściej znajdujących się w większych ośrodkach) - w dużej mierze upodobniają się do stylistyki znanej z innych państw, tracąc tym samym to, co charakterystyczne jest właśnie dla "typowych czeskich gospód”. Nie należy stąd wnioskować, że w krajobrazie większego miasta tego typu piwiarnie nie występują; chodzi tu raczej o to, że w mniejszych ośrodkach, jeśli spotka się tam jakiś lokal, prawie na pewno będzie on miał tzw. swojski charakter. Wydaje się, że specyfika tego typu obiektów jest w Polsce bliżej nieznana (choć wraz z wzrostem popularności Republiki Czeskiej stan ten zapewne ulega zmianie), czego nie da się powiedzieć o klubach młodzieżowych czy restauracjach, tworzących i w Polsce, i w Czechach, a także w wielu innych miejscach nową, zupełnie inną jakość.

(Na marginesie warto zauważyć, że niejako na przecięciu owych trzech kwestii - kulturoznawczo zorientowanych rozważań nad alkoholem, swoistej „polskiej ignorancji” oraz specyfiki gospód po południowej stronie Sudetów - sytuuje się wydana niedawno obszerna, prawie 600-stronicowa, praca dotycząca kulturowych aspektów alkoholu, w której czeska rzeczywistość jest niemal nieobecna¹).

Od strony teoretycznej ważnym impulsem do podjęcia zarysowanej powyżej problematyki jest znaczenie, jakie można przypisać przejawom kultury dnia codziennego, której istotnym (a w warunkach czeskich - szczególnie istotnym) komponentem są piwo oraz hostinec. Opierając się na refleksjach Tima Edensora, wprost nawiązującego do koncepcji "banalnego nacjonalizmu” autorstwa Michaela Billiga, należy także zauważyć, że ta forma kultury pozostaje w ścisłym związku z tożsamością narodową, która „jest zakorzeniona w codzienności, w przyziemnych szczegółach interakcji społecznej, nawyków, rutynowych działań i wiedzy praktycznej”. To właśnie w tej sferze „tożsamość podlega nieustannemu odtwarzaniu w sposób pozbawiony refleksji"2. Być może więc prezentowane poniżej rozważania mogłyby w przyszłości posłużyć jako punkt wyjścia do poszukiwań paraleli pomiędzy czeską "kulturą gospody” a zjawiskiem szerszym: pewnymi wzorami tamtejszej tożsamości narodowej.

Zaprezentowane tu przemyślenia cechują się pewną dozą „narodowo ukierunkowanego subiektywizmu", co w dużej mierze wynika z faktu, iż są one wynikiem obserwacji własnych autora, poczynionych podczas wizyt w Republice Czeskiej. Istotą zastrzeżenia

J. Gately, Kulturowa historia alkoholu, przet. A. Kunicka, Warszawa 2011.

2 T. Edensor, Tożsamość narodowa, kultura popularna i życie codzienne, przeł. A. Sadza, Kraków 2004, s. 32. 
o indywidualistycznym punkcie widzenia jest to, że ma on swe źródła w konkretnej - polskiej - walencji kulturowej obserwatora, przez co, za Antoniną Kłoskowską, należy rozumieć przyswojoną i uznaną za własną kulturę i identyfikację narodową ${ }^{3}$. W tym duchu spoglądano także na kontrast pomiędzy piwiarnią polską a czeską, prowokujący czasami do głębszego namysłu. Jest zatem oczywiste, że niektóre z elementów wspomnianych w artykule być może nie stałyby się przedmiotem rozważań (lub ujęto by je w inny sposób), gdyby za punkt odniesienia przyjąć niemiecki (francuski, grecki itd.) kanon kulturowy - a przeświadczenie to wzmacnia fakt, iż obserwacja, którą się tu posłużono, nie miała charakteru standaryzowanego. Tym samym należy mieć świadomość, że ów polski zasób kulturowy autora w oczach Czechów (lub innych narodów) niejednokrotnie zaświadczać będzie również o typie nadwiślańskiej rzeczywistości. Wszystkie powyższe okoliczności niewątpliwie podnoszą znaczenie owego - jak go powyżej nazwano - „narodowo ukierunkowanego subiektywizmu". Próbując ograniczyć jego wpływ, dobrze jest - jak zaleca Michael Angrosino - współpracować z wieloma obserwatorami, „szczególnie jeśli reprezentują różnorakie punkty widzenia (a więc badacze są zróżnicowani płciowo, wiekowo, etnicznie") $)^{4}$. W tym duchu należy podkreślić, że większość z kwestii podjętych w artykule była wielokrotnie dyskutowana z osobami (w tym także z Czechami), dla których rzeczona materia nie jest obca.

Uzasadnienia wymaga w końcu decyzja o wyodrębnieniu zarówno w tytule, jak i w poszczególnych częściach niniejszych rozważań - osobno - piwa oraz gospody. Wprawdzie oba zjawiska łączą się ze sobą, to jednak uznano, że zbytnim uproszczeniem byłoby tu potraktowanie tej drugiej po prostu jako miejsca, gdzie spożywa się ów chmielowy napój. Mówiąc inaczej, choć niepodobna wyobrazić sobie prawdziwej karczmy bez piwa, to wydaje się, że ze względu na pewne osobliwości (swoiste „społeczne tło”), które mogą zwrócić uwage polskiego obserwatora, miejsce to nie jest prostym „przedłużeniem” idei konsumpcji alkoholu. I ten właśnie wątek rozwinięty zostanie poniżej.

\section{SPOLECZNY WYMIAR GOSPODY}

Podejmując myśl zasygnalizowaną w tytule niniejszej części, wypada zacząć od stwierdzenia, że w świadomości niemałej części Polaków „typowa czeska gospoda” nie zawsze jest miejscem "oswojonym”. Jak się wydaje, w pewnej mierze wynika to z przeniesienia stereotypu atmosfery wiejskich lub małomiasteczkowych barów w Polsce - zwanych niekiedy "spelunami” lub "mordowniami”, co samo w sobie jest już dostatecznie wymowne - na wizualnie podobne lokale w Czechach ${ }^{5}$. To właśnie m.in. lokalizacja baru sprzyja temu zabiegowi, gdyż wieś lub małe miejscowość mogą się niekiedy w Polsce kojarzyć ze szczególnymi (raczej niekorzystnie odbieranymi) stosunkami społecznymi, typowymi dla tego typu miejsc. Ważna jest także, szczególnie w kontekście czeskim, zazwyczaj nieznaczna w tego typu przybytkach frekwencja ze strony kobiet, które - jak uważają niektórzy - samą swą obecnością potrafią łagodzić nastroje bardziej uniesionych biesiadników.

\section{......}

A. Kłoskowska, Kultury narodowe u korzeni, Warszawa 1996, s. 112

4 M. Angrosino, Badania etnograficzne i obserwacyjne, przet. M. Brzozowska-Brywczyńska, Warszawa 2010 s. 115.

5 W tym miejscu, jak i w wielu innych, pisząc "Czechy", zgodnie z polską tradycją mamy na myśli całe państwo - Republikę Czeską. Zrezygnowano tu więc z wyodrębniania Czech, Moraw i Śląska, choć warto dodać, że akurat na Morawach stosunkowo dużą popularnością cieszy się konsumpcja wina - również obrosła właściwą sobie kulturą. 
Zdarza się również, że mężczyźni - główni goście lokalu - siedzą przy długich stołach lub ławach (co redukuje możliwość zajęcia w miarę intymnego miejsca przez osobę "z zewnątrz") i - jak to bywa w tego typu miejscach - głośno rozmawiają czy śmieją się, a przy tym częściej niż w Polsce przychodzą do swej gospody w stroju roboczym. Do tego wszystkiego dosyć często dochodzi gęsty, spowijający ich dym papierosowy.

Dlatego właśnie pierwsze wrażenie rzeczywiście może nawiązywać do tego, z czym kojarzy się westernowski saloon z czasów, gdy zdobywano Dziki Zachód. Nie powinno zatem dziwić, że w odniesieniu do powyższej kwestii można się spotkać z eufemizmami: na przykład w kontekście polskiej i czeskiej części Cieszyna Franciszek Kłosowski zauważył, że gorsze wrażenie niż ulica Głęboka robi Hlavní Třída. „Niektóre jej obiekty »tkwią korzeniami « jeszcze w latach 70. czy 80. ubiegłego wieku (np. bar "U Huberta «)"6. To prawda, że lokal ten można było (przed jego remontem) zaliczyć niemal do awangardy czeskich gospód najniższej klasy; nawet jednak taki przypadek ze względu na właściwą mu atmosferę nie powinien być utożsamiany z podobnymi wizualnie lokalami w Polsce.

Jak wiadomo, w wielu wsiach gospoda jest jednym z najważniejszych miejsc, w których na szerszą skalę podtrzymuje się relacje społeczne, a w godzinach przedwieczornych i wieczornych, gdy zamknięte są już sklepy czy instytucje publiczne, hostinec jest w zasadzie jedynym takim miejscem. Jednocześnie tym, co wyróżnia wiele czeskich wsi czy nawet małych miasteczek, jest fakt, że już we wczesnych godzinach wieczornych sprawiają one wrażenie wyludnionych. Na tym tle szczególne miejsce zajmują gospody, których żywotność tak bardzo kontrastuje z sennością „świata zewnętrznego”.

Co ciekawe, przez pryzmat piwiarni można obserwować także nawyki ogólniejsze. Jak zauważyła Zofia Tarajło-Lipowska, Czesi są przywiązani „do tzw. małych ojczyzn i do swoich tradycyjnych »hospod ", które są jakby najmniejszą czeską jednostką administracyjną. Każdy mężczyzna ma swoją "hospodę", do której chodzi na piwo"7. Kontrast z rzeczywistością polską najczęściej polega przede wszystkim na tym, że w Czechch istnieje dużo większe prawdopodobieństwo spotkania w stosunkowo niewielkiej osadzie tego typu miejsca. Historyczno-kulturowe uwarunkowania owej polskiej rzeczywistości odnajdujemy w obserwacjach Dobrochny Kałwy, która stwierdza, że lokal-instytucja, czyli wiejska karczma, odchodzi w Polsce do przeszłości w dwudziestoleciu międzywojennym. Wielorakie funkcje społeczne tego typu miejsc w XX wieku "przejęły remizy strażackie i domy ludowe. Zamiast iść do karczmy na wódkę, w międzywojennej Polsce łatwiej było kupić alkohol w sklepie lub pojechać na rowerze do pobliskiego miasteczka"8. Tendecja ta zdaje się obowiązywać także współcześnie, co oznacza, że "życie społeczne" niewielkich ośrodków w Polsce koncentruje się raczej wokół sklepów - z reguły czynnych zresztą dłużej niż w Czechach - niwelując wspomniane wyżej wrażenie swoistej pustki, cechującej wsie po południowej stronie sudeckich grzbietów.

Obecnie można się zetknąć także z innymi konsekwencjami odmiennych w obu krajach tendencji sprzed lat, przy czym o echa te najłatwiej jest tam, gdzie najczęściej dochodzi do zetknięcia kultur, czyli na pograniczu. Ciekawą obserwację znajdujemy w reportażu Jana Dziadula, który wspomniał o uchwale radnych Czeskiego Cieszyna, zakazującej spożywania alkoholu w miejscach publicznych (m.in. w parkach, nad Olzą, na przystankach

\section{......}

6 F. Kłosowski, Usługi w miastach granicznych Cieszyn i Czeski Cieszyn, [w:] Problemy społeczno-demograficzne pogranicza polsko-czeskiego na przykładzie Śląska Cieszyńskiego, J. Runge (red.), F. Kłosowski (wspótred.), Katowice 2001, s. 202.

7 Śmieszny, a przez to ciekawy. Z Zofią Tarajło-Lipowską rozmawia Agnieszka Groń, „Nowiny Nyskie”, 27.02.2006.

8 D. Kałwa, Polska doby rozbiorów i międzywojnia, [w:] Obyczaje w Polsce. Od średniowiecza do czasów wspótczesnych, A. Chwalba (red.), Warszawa 2006, s. 278. 
autobusowych). „Władze uzasadniały to walką z problemem pijaństwa”, który to problem - dodawał burmistrz polskiego Cieszyna Bogdan Ficek - w głównej mierze, niestety, stwarzają Polacy. „Nasi rodacy pokazywali polską szkołę picia. A Czesi nie mają izb wytrzeźwień"9. Jak się wydaje, rzecz całą można sprowadzić do tego, że w Czechach trudniej jest znaleźć oddanych amatorów konsumpcji alkoholu w parkach i podobnych miejscach, w czym zapewne duży udział ma fakt, że cena piwa w tamtejszych gospodach nie odstaje od swego sklepowego odpowiednika w takim stopniu jak w Polsce.

Pozostając na gruncie Cieszyna, warto wspomnieć także o tym, że - jak wynika z badań - 63\% jego mieszkańców jako cel wizyty w czeskiej części miasta zadeklarowało przed dekadą "restauracje, bary i puby", przy 11\% Czechów wskazujących na tego typu motywację do odwiedzenia części polskiej ${ }^{10}$. W sensie ogólnym dane te skłaniają do wniosku, że gospody są istotnym punktem na świadomościowej mapie Czech, jaką konstruują sobie Polacy. Obraz ten byłby jednak pełniejszy, gdyby dotrzeć do realnych motywów popularności owych lokali wśród Polaków: czy chodzi o cenową konkurencyjność czeskich gospód, panującą tam atmosferę, czy może obie okoliczności nie są tu bez znaczenia? To właśnie Cieszyn - miasto, którego mieszkańcy z racji bliskości granicy państwowej zapewne przekraczają ją częściej, niż ma to miejsce na innych obszarach pogranicza, dysponując tym samym gruntowniejszymi obserwacjami - wydaje się być odpowiednim laboratorium do wnikliwszej w tym względzie analizy.

Kontynuując wątek specyfiki czeskich gospód, można przejść do ich „wnętrza”, a ściślej - do wystroju lokalu. Mowa tu o obrusie, podkładkach pod kufel, a także ministojakach na nie, o samych szklankach, popielniczkach, a nawet o będących wyposażeniem kelnera kartkach, na których spisuje on zamówienia gości; każdy z tych elementów nawiązuje do kolorystki oraz logo marki piwa serwowanej w danym hostincu. Oczywiście powyższa charakterystyka nie zawsze jest regułą, ale wciąż jeszcze w wielu miejscach spotkać można takie właśnie połączenie "formy" i "treści”.

W kontekście wystroju gospody warto wspomnieć o specyficznym wspótistnieniu komponentów archaicznych, nieco już zużytych, a także tych stricte nowoczesnych. Z jednej strony w czeskich hospůdkach nietrudno natknąć się na nie pierwszej świeżości tapety, jak również na obrus pozostawiający swym wyglądem sporo do życzenia, z drugiej zaś - nie jest tam rzadkością zawieszony na ścianie nowoczesny telewizor, coraz częściej również rzutnik do wyświetlania programów - m.in. meczów piłkarskich lub hokejowych, stanowiących nieodzowny element atmosfery czeskiej piwiarni. (Bywa, że z podobnymi kontrastami spotkamy się także w toaletach, którym może być daleko do czystości, a w których jednocześnie światło zapala się i gasi automatycznie wraz z wejściem i wyjściem klienta). Tego typu elementy - czasem sprawiające wrażenie nieco staroświeckich, choć dzięki temu łatwo dające się odnieść do tradycyjnej, bezpretensjonalnej mieszczańskiej gospody, stanowiące o atmosferze, którą wyobraźnia pozwala skojarzyć z czasami niemal mitycznej „Cekanii" - powodują, że całość tworzy standard, który może nie przypaść do gustu Polakowi o wyższych (a także zawyżonych) aspiracjach. Jednocześnie warto mieć na względzie słowa Z. Tarajło-Lipowskiej, że w Czechach także tamtej-

9 J. Dziadul, Bliźniaki bez granic, „Polityka”, 8.12.2007.

10 R. Zenderowski, Stosunki między mieszkańcami miast podzielonych granicą państwową na przykładzie Cieszyna i Czeskiego Cieszyna (Český Těšín). Studium socjologiczne, „Studia Regionalne i Lokalne”, 2002, nr 1, s. 70 
si profesorowie „wcale nie stronią od ludowych hospod"11. Ogólnie rzecz biorąc, chodzi o to, że Polacy wydają się być zorientowani raczej na obiekty nowoczesne, upodabniające się swym stylem do stereotypowego wyobrażenia lokalu „zachodniego”, ewentualnie na te utrzymane w klimacie pseudorustykalnym. Czyżby więc raz jeszcze odnajdywała się charakterystyka „Polak-szlachcic”, ,Czech-mieszczanin"?

W gospodzie na uwage zasługuje rzecz jasna samo piwo, a w zasadzie sposób, w jaki się je podaje. Wśród części Polaków spore zaskoczenie wywołuje fakt, że realizacja pierwszego zamówienia zajmuje stosunkowo dużo czasu. Niekiedy można nawet odnieść wrażenie, że obsługa - w dbałości o jakość trunku - napełnia nim kufel przez przepisowe siedem minut. Przypuszczenie to jest o tyle uzasadnione, że czas potrzebny na nalanie piwa nie skraca się istotnie nawet wtedy, gdy w kolejce nie czekają inni klienci, jako że obsługa odstawia po prostu do połowy napełnioną szklankę i w sposób jawny zajmuje się czymś innym. Poza fundamentalną kwestią troski o jakość oferowanego produktu można tu odnaleźć nawiązanie do jednego z czeskich powiedzeń, odnoszonego zresztą do wielu sfer życia - to chce klid, co można przetłumaczyć jako "to wymaga spokoju/czasu”, "nie ma się co spieszyć". A już z pewnością - spróbujmy wczuć się w istotę tego przesłania nie ma się co spieszyć w gospodzie, która ma być miejscem relaksu.

Koniecznie należy też wspomnieć o swoistym „dopełnieniu” trunku - pianie, niejednokrotnie mającej konsystencję niemalże bitej śmietany. Nie będzie żadną ekstrawagancją stwierdzenie, że w czeskiej gospodzie czymś nie do pomyślenia jest piwo pozbawione tego „zwieńczenia”, swym wyglądem przypominające wówczas raczej herbatę. Z sytuacją taką często zaś spotykamy się w rzeczywistości polskiej, gdzie duże znaczenie ma raczej to, żeby piwo podane było jak najszybciej², sama zaś piana, nie dość że utrudnia sprawną konsumpcję, to jeszcze może być wykorzystana przez nieuczciwego barmana jako zasłona dla faktu, że produkt nie został podany dokładnie w takiej ilości, w jakiej został zamówiony. Przyjmując ową nadwiślańską perspektywę, łatwiej też znajdzie się wyjaśnienie dla faktu, że w polskich barach nawet czeskie piwo bywa pozbawione piany, co dla czeskiego konsumenta stanowiłoby niemal kamień obrazy.

Odrębnym komentarzem warto opatrzyć sposób, jaki wielu czeskich kelnerów wciąż jeszcze wybiera, aby zachęcić klienta do wypicia następnego piwa. Chodzi o nic innego, jak postawienie przed nim kolejnego pełnego kufla - choć żadne zamówienie nie zostało złożone, a sam konsument nie musi być tzw. stałym bywalcem, którego zwyczaje obsługa dobrze zna. Zachowanie takie może oczywiście kojarzyć się z próbą wymuszenia na kliencie czegoś, na co nie ma on ochoty, jednak w praktyce trudno chyba wyobrazić sobie taką reakcję. Zachęcony w ten sposób biesiadnik - szczególnie, gdy nie jest on stałym gościem danego lokalu - prędzej zapewne pomyśli o pewnej familijności, która tak szybko stała się także jego udziałem, niż poczuje, że ktoś próbuje na nim wywrzeć presję. Ponadto, dla „polskiego ucha” intrygująca jest już sama werbalizacja zaproszenia do dalszej konsumpcji; skierowane do siedzących w gospodzie mężczyzn pytanie: chlapy, ještě pivečko/ pivčo?, nie jest przecież ani czymś powszednim, ani też - by się tak wyrazić - emocjonalnie neutralnym.

11 Z. Tarajło-Lipowska, Kapoan. O czeskim dla Polaków, być może mało zaawansowanych, ale mocno zainteresowanych, Wrocław 2000, s. 31.

12 Kilka lat temu w jednym z lokali na Żywiecczyźnie obsługa, zapytana o powody, dla których zaniechano sprowadzania piwa z nieodległej Słowacji, wskazała właśnie na to, że klienci, poirytowani faktem, iż piwo „tak długo się leje”, rezygnowali z zakupu owego gatunku z importu. Nie jest to zresztą jedyna ilustracja tego zjawiska. 
W tym miejscu należy również nawiązać do kwestii samej obsługi w czeskich gospodach. Nasuwa się tu następujące spostrzeżenie: niezależnie od kategorii lokalu, zjawiskiem w zasadzie niespotykanym jest brak kelnera. Nie ma znaczenia także to, czy w danym lokalu podaje się coś poza alkoholem (a trzeba tu dodać, że w ostatnich latach asortyment niemałej części czeskich gospód zredukowany został do alkoholu i drobnych przekąsek jak paluszki, chipsy itp.), co oznacza, że nawet w „klasycznej” piwiarni, nawet najniższego sortu, nie spotkamy ludzi stojących przy szynkwasie w kolejce po piwo. Ci zaś, którzy nie zreflektowaliby się w porę co do miejscowych obyczajów, zostaliby zapewne poproszeni przez obsługę, by sobie usiedli.

Czeski kelner zazwyczaj nie przesadza z nadmierną grzecznością, co jednak nie oznacza, że przyjmuje on postawę ignorującą. Nie sprawia wrażenia kształconego w nowoczesnych trendach restauratora, nie kreuje się na "showmana”, który za wszelką cenę pragnie zyskać względy gościa, lecz jest raczej „rzemieślnikiem” - w neutralnym lub nawet pozytywnym tego słowa znaczeniu; jest po prostu kimś, kto zna się na swym fachu i stara się go rzetelnie wykonywać. Tym samym klient nie znajduje impulsu do pretensjonalnego wrażenia, że jest „panem”, któremu pozwolono odczuwać swą chwilową wyższość nad obsługą. W ten sposób obie strony zachowują się w sposób (bardziej) naturalny, pozostając dla siebie partnerami - co jednocześnie wpisuje się w czeską słabość do egalitaryzmu.

Z kelnerowaniem ściśle wiąże się kwestia napiwków. Co prawda są one w czeskich hospodach - także tych, gdzie nie serwuje się posiłków - zjawiskiem dość powszechnym, jednak zwraca uwage to, że są stosunkowo niskie. Mając na względzie "typową" czeską gospodę, należy przyjąć, że kwota ta - jak mówi dosłowne tłumaczenie angielskiego odpowiednika słowa "napiwek" (tip) - to rzeczywiście „końcówka”, i to ściśle rozumiana. Nie powinna więc zaskakiwać sytuacja, w której przy rachunku opiewającym na 88 koron, klient zaokrągla go nie do 100, lecz - do 90 koron. Przeliczając ten napiwek na złotówki, otrzymujemy (przy kursie 1 korona = 0,17 zł) kwotę ledwie 34 groszy, co w polskiej rzeczywistości przypuszczalnie zostałoby uznane za kpinę z obsługi. Wrażenie to ulega wzmocnieniu, gdy uzmysłowimy sobie, że przy wciąż stosunkowo niskich w Czechach cenach piwa (także w gospodach) zapłata rzędu wspomnianych 88 koron oznacza, iż kelner przynosił gościowi ów trunek cztery-pięć razy - liczba, która (poza wszystkim innym) mogła przecież posłużyć do nawiązania z nim niejakiego kontaktu, co samo przez się powinno sprzyjać większej szczodrości klienta. Czym więc można tłumaczyć tę czeską specyfikę? Pewnym tropem wydaje się duża częstotliwość, z jaką przeciętny Czech odwiedza swą gospodę, co oznacza, że - po pierwsze - nie jest ona dla niego jakąś „odświętną instytucją", wymagającą szczególnej jego postawy, po drugie zaś, że przy niemal codziennej obecności owego bywalca, z hojnie udzielanych przezeń napiwków w ciągu jednego tylko miesiąca uzbierałaby się niemała kwota. Być może znaczenie ma także poruszony wcześniej wątek „naturalnego" zachowania kelnera. Wszystko to jednak są tylko przypuszczenia, a pytanie to pozostanie bez wyczerpującej odpowiedzi.

Zamykając kwestię kelnerowania, warto wspomnieć o specyficznym sposobie zapisywania przez obsługę treści i liczby zamówień klienta. Do celu tego służy specjalna, niewielka karteczka zwana lístek, przydzielana poszczególnym gościom lokalu, zazwyczaj przedstawiająca logo serwowanego w nim piwa. Choć kartka ta raczej nie zwraca uwagi swego właściciela, gdyż często położona jest zapiskami do dołu, stanowi jednak ważny element dbałości o to, by żadna ze stron - właściciel lokalu, a szczególnie klient - nie miała wątpliwości, że kwota rachunku nie odpowiada zrealizowanym zamówieniom (a ewentualność taką łatwo jest sobie przecież wyobrazić w przypadkach szczególnie intensywnych biesiad). 
Mówiąc o czeskich gospodach, można wspomnieć o popularności, jaką w Polsce w ostatnich latach cieszą się w kontekście gastronomicznym archaiczne nieco wyrażenia typu „jadło”, „karczma” czy „gościniec”. W ten sposób - świadomie lub nie - nawiązując do całkowicie naturalnych we współczesnej czeszczyźnie słów jídlo, krčma, czy hostinec, pojawia się szansa na zredukowanie uczucia śmieszności, jakie wywołuje w Polsce mowa Czechów (zjawisko to jest zresztą dwustronne). Przy okazji jednak wypada zauważyć, że owa swoista "rehabilitacja” - o ile do niej rzeczywiście miałoby dojść - u swych źródeł mieć będzie polską modę na jakąś formę współczesnej chłopomanii, „rustykalnej nostalgii” czy cepelii, a już na pewno - komercyjnie eksploatowane pragnienie choćby symbolicznego przeżycia atmosfery dawnych czasów. W konsekwencji, nie od dziś niektórzy konsumenci odnajdujący w tym językowo-kulturowym zabiegu wyraźne ślady przesadnie merkantylnego stosunku do rzeczywistości, odrzucają lokale eksploatujące tego typu nazewnictwo.

Osobnym, niezwykle bogatym wątkiem jest obecność gospód w literaturze czeskiej. Chyba najbardziej znaną ilustrację atmosfery piwiarni stanowią Haszkowe Przygody dobrego wojaka Szwejka podczas wojny światowej, jednak współistnienie tego typu treści pojawia się często także w innych kontekstach. Sam autor owego wiekopomnego dzieła - jak pisał Leszek Pułka - wcześnie osierocony przez ojca, zrozumiał, że świat przy kuflu piwa bywa szczerszy od salonów, bo pełen [jest] namiętności wyrażanych wprost"13. I jeszcze opinia Bohumila Hrabala, która może stanowić zachętę do zgłębienia tematyki z pogranicza gospody i prozy: „Okazuje się, że niedorzeczności, które ludzie wygadują w knajpach, mają sens i mogą stworzyć coś, co nazywamy literaturą. [...] Można powiedzieć, że mój sposób mówienia i pisania jest ściśle związany z gospodami" - stwierdzał ów pisarz w 1989 roku14.

Należy także zauważyć, że niejedna z czeskich piwiarni uwiecznionych w dziełach tamtejszej literatury znajduje się W przeżywającej obecnie swój turystyczny "złoty wiek" Pradze. Jak podają autorzy książki-przewodnika po tym mieście (Biblioteka "Gazety Wyborczej"), "Gospoda U Kalicha na Nowym Mieście, unieśmiertleniona przez Jarosława Haszka jako miejsce spotkania dobrego wojaka Szwejka i jego druha "o szóstej wieczór po wojnie«, stała się niestety barem tematycznym z zawrotnymi cenami, sklepikiem z pamiątkami i rzędem autokarów przed wejściem". W związku z tym trzeba krytycznie podejść do dalszego ciągu opisu tego lokalu: "Z drugiej strony to dobre miejsce dla zachodniego turysty, chcącego zapoznać się z czeską kulturą piwną bez barier językowych i na zachodnim poziomie usług"15. Należy bowiem zapytać, czy usytuowana w kosmopolitycznym centrum współczesnej Pragi i zorientowana na zachodnioeuropejską klientelę piwiarnia może uchodzić za ilustrację autentycznej (a nie: wystawionej na sprzedaż, czyli podretuszowanej) kultury czeskiej? Z autorami publikacji można się natomiast zgodzić w kwestii tego, że obecnie w stolicy Czech „przypadkowe znalezienie lokalu z prawdziwego zdarzenia jest mało prawdopodobne - raczej wymaga to precyzyjnej nawigacji"16, choć jednocześnie uwagę tę trafniej byłoby ograniczyć do turystycznego centrum.

Ogólnie rzecz biorąc, czeskiego ducha w odniesieniu do owej specyficznej materii, jaką jest piwiarnia, w kilku lapidarnych, acz treściwych zdaniach nakreślił Edmund Lewandowski: „W gospodzie koncentruje się życie męskiej części narodu. Na każdej chyba ulicy

13 L. Pułka, Dla Czechów polévka je grunt, "Gazeta Wyborcza” (dodatek „Wrocław”), 22.04.2002.

14 Za: Z. Pietrasik, Czeski film, polska duma, "Polityka”, 19.05.2007.

15 Miasta marzeń, t. 4, Praga, E. Kosiba (red.), Warszawa 2009, s. 67.

16 Ibidem. 
jest gospoda. Mężczyźni lubią tu przesiadywać. Można porozmawiać lub pomilczeć. Picie piwa jest, obok hokeja, piłki nożnej i tenisa, sportem narodowym. Rozmowy składają się z monologów, a nie kłótliwych dyskusji. Rozmówcy nie przerywają sobie, lecz uważnie słuchają. Nie muszą popisywać się przed kobietami. Po kilku piwach chętnie siadają wspólnie przy wielkim stole. Potrafią kpić sobie z siebie, uznając wady za zalety"17. Obraz ten, nawet jeśli gdzieniegdzie nazbyt idylliczny, a niekiedy przejaskrawiony, pokazuje, że lokalny hostinec jest miejscem, które w czeskiej rzeczywistości znaczy bardzo wiele. Jak zresztą stwierdził Jiří Brodský, odwiedzanie gospody - obok budowania domku letniskowego - było najpowszechniejszym sposobem spędzania czasu wolnego w okresie komunizmu. Autor ten zauważył również, że dyskusje i spotkania w gospodach z innymi ludźmi były wówczas jedyną formą relacji społecznych w wymiarze horyzontalnym ${ }^{18}$. Być może więc - co zasygnalizowano na wstępie niniejszego artykułu - w sensie ogólniejszym warto poważniej zastanowić się nad znaczeniem gospody dla typu stosunków między członkami czeskiego społeczeństwa, a także dla kształtu tamtejszej tożsamości narodowej.

Opis realiów czeskiej gospody byłby niepełny, gdyby nie wzbogacić go o jakąś anegdotę. Do tego bodaj najbardziej nadaje się połączenie tamtejszej wstrzemięźliwości w stosunku do Kościoła z jej przeciwieństwem, czyli wzmożoną konsumpcją piwa. Zgodnie z czeską prawdą - wskazywał Leszek Mazan - „"pragnienie jest w zasadzie niezaspokajalne«, ale spróbować można, a nawet trzeba: bardziej bowiem uczciwie jest siedzieć w gospodzie i myśleć o kościele, niż siedzieć w kościele i myśleć o gospodzie"19.

\section{"PIWO JEST LEKARSTWEM, A MY JEGO PACJENTAMI", CZYLI CZESI A PIWO}

Przyjrzawszy się już powyżej czeskim odniesieniom do gospody i jej głównego asortymentu, można by zastanowić się nad zasadnością wyodrębniania kolejnej części, która na dodatek w swym tytule zawiera słowo „piwo”. Dlatego należy tu zaznaczyć, że poniższe obserwacje w dużej mierze abstrahują od gospody jako zjawiska kulturowego, koncentrując się na samym napoju. O tym zaś, że krok taki - nawet jeśli uznać go za przejaw nadmiernej uwagi poświęcanej samemu tylko trunkowi - jest uzasadniony, może świadczyć zawarty w powyższym nagłówku cytat, będący jedną z kilku „złotych myśli”, jakie widnieją we wnętrzu pewnej piwiarni w Usti nad Łabą.

W Czechach piwo to niewątpliwie "żywioł ogólnonarodowy", w poprzek przecinający wszelkie kategorie. Nie może więc być zaskoczeniem, że postać byłego prezydenta Republiki, Václava Havla, sprzyja wrażeniu, iż - mówiąc kolokwialnie - przykład idzie z góry. Pomijając fakt, że polityk ten (a jednocześnie pisarz i dramaturg) pracował przed laty w browarze (w podkarkonoskim mieście Trutnov), to - jak powszechnie wiadomo żywił on szczególną sympatię do gospód. Oto jak opowiadał o swych upodobaniach i nawykach: "Jak wszyscy wiecie, jestem człowiekiem lubiącym knajpy, którego wszystko ciekawi i nic nie szokuje". Snując rozważania na temat amerykańskich nawyków żywieniowych, V. Havel stwierdzit: "Myślę, że nie jestem alkoholikiem, ale żeby nie popić jedzenia piwem czy winem, to mi się nie mieści w głowie". Natomiast w kontekście pewnego, stresującego dlań mityngu na jednym z amerykańskich uniwersytetów, wspominat:

17 E. Lewandowski, Pejzaż etniczny Europy, Warszawa 2004, s. 348

18 J. Brodský, The Czech Experience of Identity, [w:] National and European Identities in EU Enlargement. Views from Central and Eastern Europe, P. Drulák (ed.), Prague 2001, s. 31-32.

19 L. Mazan, Praga: Kde domov moj, „Polityka”, 24.08.1996. 
"Musiałem potem sporo wypić, po czym następnego dnia czułem się fatalnie" 20. Również sam Andrzej Jagodziński, tłumacz przywołanej wyżej książki, oddaje stan „biesiadnego ducha" Havla, mówiąc, że fantastycznie czuł on się w praskich gospodach. "I nic dziwnego, że do protokołu prezydenckiego wprowadził rytuat, który dotyczył każdej oficjalnej wizyty - koronowane i niekoronowane głowy państw zapraszał na piwo do prawdziwej piwiarni, która w tym czasie była otwarta także dla innych gości. [...] Ten rytuał miał swój prosty cel - Havel chciał pokazać gościom nie wystrój restauracji, ale prawdziwe życie w Czechach"21. W tym wątku mieści się świętowanie przez eksprezydenta Republiki Czeskiej swych urodzin w praskich piwiarniach w towarzystwie muzyków z grupy The Rolling Stones czy wspólna wizyta w gospodzie z prezydentem Billem Clintonem.

I chociaż również polscy politycy, także ci najwyższego szczebla, dali dowód, że - by raz jeszcze posłużyć się kolokwializmem - „za kołnierz nie wylewają”, to jednak trudno uciec od pytania, dlaczego $\vee$. Havel o swych alkoholowych przygodach mówił tak, jakby po prostu snuł ciekawą opowieść, nad Wisłą zaś z tego typu relacji robi się niemal wiadomość dnia. Czy chodzi tu o format danej postaci, o skutki i styl biesiadowania, poziom hipokryzji oraz tolerancji społeczeństwa, czy może wszystkie te okoliczności (a także jakieś inne) do pewnego stopnia zachowują swą ważność?

Wprawdzie czeskie piwo ma z reguły mniejszą moc od swego polskiego odpowiednika, to jednak na południe od granic RP co innego wydaje się mieć znaczenie. Dość wymowny jest sam fakt, że tamtejsze piwa klasyfikuje się raczej ze względu na poziom ekstraktu (np. tzw. desítka czy dvanáctka) niż właśnie zawartość alkoholu czy markę. Na czeskim rynku stosunkowo trudno jest spotkać piwa o szczególnie wysokiej zawartości alkoholu - tzw. strongi. Jeśli spostrzeżenie to odnieść do popularności, jaką tego typu piwa cieszą się w Polsce, wówczas można odnieść wrażenie, że w większym stopniu niż w Czechach chodzi tu o szybkie wywołanie efektu nietrzeźwości. To zaś oznaczałoby, że konsumpcji alkoholu tatwiej można w Polsce nadać charakter autoteliczny, podczas gdy po drugiej stronie sudeckich grzbietów w większym stopniu chodzi o cieszenie się smakiem napoju. Warto również wziąć pod uwagę fakt, że piwo oferowane w polskich lokalach jest z reguły bardziej od swego czeskiego odpowiednika gazowane, co z pewnością przyczynia się do tego, że - jak sugerują badania konsumenckie - większa część Polaków nie jest w stanie rozpoznać gatunku piwa, także swego - rzekomo - ulubionego. Kuszące jest zatem stwierdzenie - być może w pewnej mierze uproszczone - że Polacy piją bardziej na ilość, Czesi zaś - także na jakość. Jednocześnie bowiem trudno jest pominąć fakt, że - z jednej strony - to Czesi są światowymi liderami w konsumpcji piwa per capita (nie stroniąc zarazem od alkoholi wysokoprocentowych), z drugiej zaś - że jeden z najpowszechniejszych czeskich stereotypów na temat Polaków mówi, iż są to pijacy.

Mając na względzie to, jak wielkie znaczenie ma dla Czechów - zarówno dla obsługi, jak i klientów - jakość piwa, warto w tym miejscu nawiązać do przypomnianej przez Wojciecha J. Bursztę i Waldemara Kuligowskiego kwestii planów wykupienia przez amerykański koncern piwowarski Budweiser czeskiego browaru o tej samej nazwie. Biznesowa propozycja została jednak odrzucona, ponieważ „Czescy piwowarzy obawiali się ujednolicenia metod produkcji. Stąd mamy dzisiaj na rynku dwa budweisery: "szybki «, amerykański, który gasi pragnienie, oraz "powolny«, czeski, służący degustacji, który cieszy pełnią

20 V. Havel, "Tylko krótko, proszę". Rozmowa z Karelem Hvízd'alą, zapiski, dokumenty, przeł. A.S. Jagodziński, Kraków 2007, s. 24, 71, 136.

21 Niestychanie zajęty cztowiek. Z Andrzejem Jagodzińskim rozmawia Magda Piekarska, "Gazeta Wyborcza” (dodatek "Wrocław"), 3.06.2009. 
aromatu i niepowtarzalną złocistą barwą"22. Dla kontrastu można w tym miejscu wspomnieć o tym, że w Polsce, nawet w lokalach, gdzie serwuje się piwo z beczki, goście nierzadko decydują się na trunek z butelki, a nawet z puszkiin. Wybór swój Polacy uzasadniają obawami co do świeżości piwa z nalewaka, wskazując również na brak pewności, czy nie zostało ono rozcieńczone wodą. Przyglądając się strukturze zamówień w czeskich gospodach, można dojść do wniosku, że tamtejszym piwoszom tego typu obawy wydałyby się niedorzecznością, dodatkowo utwierdzając ich w przekonaniu, że "nie ma to jak czeskie piwo". Z powyższym wątkiem łączy się też zresztą ciekawa prawidłowość: w Czechach, być może dlatego że tzw. lane piwo pije się tam w wielkich ilościach, bardzo trudno jest o sytuację, że "beczka się skończyła” i nie ma kolejnej, z czym nierzadko można spotkać się w Polsce.

Troskę o jakość chmielowego trunku widać zresztą także przez pryzmat pewnego zwyczaju. Niezależnie od tego, czy kolejne piwo podane jest na życzenie klienta, czy - o czym wspominano wyżej - z inicjatywy samej obsługi, należy liczyć się z tym, że jeśli na dnie szklanki został jeszcze przystowiowy "tyk”, kelner zabierze ją wraz z dostarczeniem nowego piwa. W Polsce tego typu zachowanie obsługi mogłoby się spotkać z uwagą klienta, że nie wszystko jeszcze wypił. Jednak w Czechach - gdy uwzględnić szersze tło tamtejszych cen - kwota, jaką należy w gospodzie uiścić za piwo, wciąż jest na tyle niska, że - właśnie w połączeniu z troską o jakość napoju - trudno byłoby się w tym kontekście spotkać z głosem protestu. Po co więc - można próbować streszczać czeski punkt widzenia - psuć sobie doznania resztkami tego, co już straciło swój walor, skoro za niewielkie pieniądze znów można cieszyć się pełnią smaku?

Ciekawostką jest również to, że w Czechach nie spotyka się piwa podawanego w plastikowych kubkach, które części piwoszy wydają się przeczyć estetyce konsumpcji tego trunku, choć w sklepach, od stosunkowo niedługiego czasu, dosyć często spotyka się już piwa w plastikowych butelkach, i to o objętości większej niż "tradycyjne" 0,5 litra. W tamtejszych gospodach nie jest praktykowany obyczaj picia piwa grzanego, a także z sokiem (osoby, które eksperymentowały w Czechach z takim zamówieniem, z zaskoczeniem odkryły, że podano im piwo oraz butelkę pomarańczowego czy grejpfrutowego napoju). Wydaje się, że tego typu miksturę trudno byłoby wytrawnemu smakoszowi piwa pogodzić z doznaniami płynącymi z konsumpcji chmielowego trunku.

Zarazem jednak należy zauważyć, że na piwo z sokiem - czy, mówiąc precyzyjniej: syropem - decydują się przede wszystkim kobiety, które - jak już wspomniano - rzadko pojawiają się w „typowych” gospodach. Niewykluczone więc, że to właśnie próba zmiany tej prawidłowości, jak również szerzej - pozyskania pokaźnej grupy klientów - spowodowała, iż w ostatnim czasie na (nie tylko) czeskim rynku mamy do czynienia z istną ekspansją tzw. piw smakowych (typu "radler”), o zawartości alkoholu ok. 2\%. Innego rodzaju novum, będącym niejako w opozycji do sytuacji poprzedniej, stanowi "Double" - piwo typu „porter" (rekordowe 24\% ekstraktu oraz 10,5\% alkoholu), jakie ma w swej ofercie browar Primátor, reklamujący tę odmianę jako "najmocniejsze czeskie piwo od 1990 roku i jedno z najmocniejszych w Europie" 24 .

22 W.J. Burszta, W. Kuligowski, Sequel. Dalsze przygody kultury w globalnym świecie, Warszawa 2005, s. 101.

23 W tym miejscu warto przytoczyć ekstrawagancką opinię bacznego obserwatora czeskiej rzeczywistości, norweskiego dziennikarza i pisarza Terje B. Englunda, który w kontekście struktury popytu na ów chmielowy napój na tamtejszym rynku stwierdzit, że tylko głupi obcokrajowcy kupują piwo w puszkach (T.B. Englund, The Czechs in a Nutshell. A User's Manual for Foreigners, Praha 2004, s. 39).

24 Zob. www.primator.cz/pivo [pobrano 6.08.2012]. 
Rzeczywistość czeska wyróżnia się także swoistą „piwną regionalizacją”, gdy chodzi o ów trunek podawany z beczki. Dany region wytrawnym piwoszom, także z innych części Republiki, często kojarzy się bowiem z konkretną marką tam warzoną, którą jednocześnie najczęściej podaje się w lokalnych hostincach. Regularność ta jest słabiej widoczna w większych ośrodkach, gdzie na szerszą skalę dystrybuowane są gatunki ogólnoczeskie, jednak na prowincji wciąż jeszcze łatwo w tym względzie o swoistą "monokulturę". Jednym z bardziej wyrazistych jej przykładów jest czeska część Śląska Cieszyńskiego, gdzie w wiejskich lub małomiasteczkowych gospodach trudno jest o piwo inne niż "Radegast”.

Co ciekawe, browar ten pojawia się także przy okazji opisu trasy rowerowej po owym regionie. Znajdujące się na tym szlaku lokale - zaznaczone na specjalnej mapie turystycznej i, rzecz jasna, oferujące rzeczony trunek - posiadają także okolicznościową pieczątkę ozdobną, na której, oprócz informacji o nazwie i lokalizacji obiektu, znalazło się także miejsce dla logo piwa. W związku z tym, z jednej strony, można zasadnie pytać, jak konsumpcję tego napoju połączyć z bardzo popularną w Czechach jazdą na rowerze, w świetle rygorystycznego w tym względzie tamtejszego prawa (dopuszczalna norma dla kierowcy pojazdu to $0,0 \%$ alkoholu we krwi). Z drugiej strony, warto się zastanowić, czy w polskiej rzeczywistości przeciwko takiemu zestawieniu - piwa i krajoznawstwa - nie zaprotestowaliby turyści: po pierwsze - w obawie przed groźbą dalszego obniżania poziomu kultury jazdy na rowerze po szlakach turystycznych; i po drugie - w obronie swoistego etosu, zgodnie z którym „prawdziwa” turystyka i alkohol wzajemnie się wykluczają. Przyjmując zaś perspektywę ogólniejszą, w odniesieniu do marki „Radegast” i Śląska Cieszyńskiego można zapytać, w jakiej mierze ów, tak silnie związany z tym obszarem, gatunek piwa tworzy tamtejszą, skądinąd stosunkowo mocno rozwiniętą, tożsamość regionalną.

Na koniec tej części warto jeszcze odnieść się do kwestii cen piwa. Wydaje się, iż ma ono do tego stopnia renomę napoju narodowego, że - jako coś najzupełniej powszechnego - nie może kosztować zbyt dużo, ponieważ wysokie ceny groziłyby stworzeniem pewnych podziałów w tak podstawowej kwestii - a tego (stereotypowo bądź nie) egalitarystycznie zorientowane społeczeństwo czeskie mogłoby nie tolerować. Co innego wykorzystywanie przybyszów - tu spotkamy się z kontrastami, jakich nie ma nawet w Polsce. Na przykład w Warszawie trudno byłoby o sytuację, w której cena piwa w lokalu, nawet w szczególnie atrakcyjnym turystycznie miejscu, byłaby o kilkaset procent wyższa niż ogólnie w tzw. centrum - a z taką właśnie sytuacją spotkamy się w Pradze. Inaczej mówiąc, na starówce nadwiślańskiej stolicy piwo może być stosunkowo drogie, ale jednak mieścić się w przedziale - powiedzmy - 10-20 zł, natomiast w czeskiej stolicy trunek ten można kupić za 25-30, ale i za ok. 100 koron.

\section{NÁDRAŽNÍ RESTAURACE, CZYLI "POCIĄG DO PIWA"}

Nádražní restaurace (restauracja dworcowa) to instytucja dość osobliwa, a nawet fenomen sam w sobie. Jest to lokal na dworcu kolejowym (często także na niewielkich stacjach przelotowych), służący podróżnym, ale i miejscowym. Wprawdzie również w Czechach można zauważyć, że współczesność odległa jest od złotego okresu dla kolei żelaznej o około 100 lat - co siłą rzeczy nie pozostaje bez wpływu na liczbę i kondycję restauracji dworcowych - jednak państwo to wciąż pozwala w tym względzie przywrócić pamięci obrazy minionych czasów. (A jest się do czego odwoływać; jak pisze Antoni Kroh, 
sam Franciszek Józef I, objeżdżając koleją odległe krainy monarchii, „Jadał w restauracjach dworcowych, tak było najprędzej i najwygodniej. Oraz dlatego, że były to restauracje najelegantsze" ${ }^{25}$ ). Nawiązanie do przeszłości w żadnym wypadku nie jest tu więc zawoalowaną ironią pod adresem Czechów. Mając na względzie polską rzeczywistość, myśl tę powinno się raczej odebrać jako refleksję nad próbą połączenia dobrze rozumianej tradycji (dbałość o wygodę pasażera państwowej instytucji, jaką wciąż w dużej mierze jest czeska kolej) z myśleniem przyszłościowym (kondycja tamtejszego transportu szynowego), co zresztą wydaje się być jednym z czeskich talentów.

Podobnie jak w odniesieniu do ogółu czeskich gospód wiejskich lub małomiasteczkowych, myśląc o restauracjach dworcowych, należy wspomnieć o dosyć dużym zróżnicowaniu, gdy chodzi o ich kategorie. Coraz częściej można dostrzec obiekty nowe (np. na stacji w Karwinie) lub nawiązujące do klimatów secesyjnych (np. na dworcu w Brnie), zaświadczające o tym, że dworzec kolejowy wciąż ma szansę być miejscem istotnym na mapie danego miasta. Są jednak i takie, którym raczej trudno byłoby zainteresować swoją ofertą osoby inne niż swych stałych bywalców (np. wyjątkowo niskiej kategorii lokale na głównych stacjach w powiatowym Šumperku czy wojewódzkim Libercu), zniechęcające swą atmosferą do wizyty nawet pasażerów zmuszonych oczekiwać na połączenie, czy piwiarnia na stacji w Usti nad Orlicą z płatnym wychodkiem (absolutna rzadkość). Wydaje się, że w kwestii owego zróżnicowania jakości łatwo jest doszukać się paraleli z rzeczywistością Galicji przełomu XIX i XX wieku. Jak bowiem zauważył Dariusz Opaliński, „Między lokalami I i II klasy a lokalami III klasy istniała [wówczas] kolosalna różnica. Większość barów III kategorii oprócz tego, że często nie spełniała podstawowych wymogów lokalowych i sanitarnych, świadczyła usługi daleko odbiegające od przyjętych standardów"26. Pomijając jednak tego typu przypadki, można chyba stwierdzić, że obecnie najwięcej jest takich restauracji dworcowych, które - niemalże przeniesione ze scenerii filmu "C.K. Dezerterzy" - wciąż po części oddają klimat „poczciwej” austriackiej instytucji, zaświadczając jednocześnie, iż nadal są one istotnym elementem czeskiej „rzeczywistości kolejowej"; czymś, czego podróżny ma prawo oczekiwać.

Z polskiej perspektywy szczególnie intrygujące może być to, że w rzeczonych czeskich stacyjnych lokalach oczywiście podaje się piwo. Pomijając tych klientów, którzy do restauracji dworcowych przychodzą nie ze względu na przymusowy przestój w podróży, serwowanie owego trunku zdaje się odzwierciedlać szerszy trend znany z przeszłości. W Europie - jak pisał Wojciech Tomasik - aż do zakończenia II wojny światowej „bufet kolejowy pozostanie miejscem, gdzie można łagodzić »febrę podróżną za pomocą któregoś z tradycyjnych napojów alkoholowych" ${ }^{27}$. Co ciekawe, w przypadku niejednej z czeskich dworcowych gospód, wystawiony na zewnątrz lokalu „ogródek” niemalże graniczy z pierwszym torem (który, co prawda, najczęściej jest nieużywany). Również w tym względzie warto odwołać się do obrazów z przeszłości, wszak to, że dziś z wielu z tych lokali można wyjść od razu na peron, także stanowi echo zaobserwowanych przez D. Opalińskiego dawnych założeń architektonicznych dworców monarchii austro-węgierskiej.

W Polsce tymczasem nawet na dworcach w dużych miastach raczej nie sposób jest - ze względu na stosowny przepis - znaleźć obiekt mający w swym asortymencie "napoje procentowe". Tłumaczy się to chęcią ograniczenia liczby wypadków z udziałem ludzi pod wpływem alkoholu, co wydaje się uzasadnieniem zgoła absurdalnym. W Czechach,

25 A. Kroh, O Szwejku i o nas, Warszawa 2002, s. 81

26 D. Opaliński, Usługi gastronomiczne na kolejach galicyjskich, "Kwartalnik Historii Kultury Materialnej”, 2001, nr 3, s. 214

27 W. Tomasik, Ikona nowoczesności. Kolej w literaturze polskiej, Wrocław 2007, s. 136. 
gdzie - jak wspomniano - rzeczywistość jest w tym względzie całkowicie odmienna, na stacjach kolejowych spotyka się - w porównaniu z Polską - dużo mniej osób, których stan wskazuje na nadmierne spożycie alkoholu. Nie warto przy tym wskazywać, że Polacy są społeczeństwem prawie czterokrotnie liczniejszym niż ich południowo-zachodni sąsiedzi; należy raczej zwrócić uwagę na to, że - pomijając już konsumpcję per capita - gdy chodzi o ilość podróży koleją odbywanych rocznie przez przeciętnego obywatela, Czesi wyprzedzają Polaków mniej więcej trzykrotnie. Warto także wspomnieć, że wśród Czechów rzadko spotyka się pasażerów, którzy w podróż pociągiem zabieraliby piwo, co jest zjawiskiem dosyć częstym w polskiej rzeczywistości (nie mówiąc o swoistych "komiwojażerach", dystrybuujących ów trunek w wagonach PKP). Być może chodzi tu o to, że w Czechach na dalekich trasach łatwiej jest o pociąg prowadzący wagon restauracyjny, w którym oferuje się piwo; w Polsce natomiast nawet w ekskluzywnych pociągach InterCity podaje się jedynie bezalkoholową odmianę tego napoju ${ }^{28}$.

Na zakończenie niniejszej części warto przywołać wątek symbolicznie spajający piwo i kolej jako istotne elementy rzeczywistości po drugiej stronie Sudetów. Jacek Baluch (były ambasador RP w Pradze), tłumacząc na język czeski Lokomotywę Juliana Tuwima, nie mógł nie nawiązać właśnie do piwa, czego przecież w oryginale nie znajdziemy. "Piwo - tłumaczył swą decyzję L. Mazanowi - to tutaj [w Czechach] napój narodowy, dzieci przynoszą je w dzbankach tatusiom z gospody. Gdyby Tuwim pisał ten wiersz po czesku, ręczę, że o piwie by nie zapomniał". Tego typu ingerencja w oryginał wydaje się czynić zadość zasadzie uwzględniania w przekładzie kontekstu kulturowego, tym bardziej że przecież w trzecim wagonie siedzą grubasy i jedzą špekáčky - „rodzaj ulubionych kiełbas [które] musi się jeść z piwem, inaczej czeskie dziecko natychmiast wyczuje fałsz". I tak, z racji tego, że „przekład ma być przecie zgodny i z duchem języka, i z duchem narodu", w tłumaczeniu J. Balucha czeska lokomotywa ciągnie w książeczce dla dzieci cały wagon z piwem ${ }^{29}$.

\section{UWAGI KOŃCOWE}

Celem powyższych rozważań była próba opisu "rzeczywistości piwnej” Republiki Czeskiej. Jego nieodzownym elementem powinna jednak być świadomość, że w ostatnich kilkunastu latach tamtejszy rynek piwny uległ (i wciąż ulega) przeobrażeniom. W tym czasie bowiem zauważalnie zmniejszyła się liczba lokali (w tym "tradycyjnych”), zmienia się ich charakter (rzadziej dysponują one kuchnią), wygląd zaś ulega „unowocześnieniu”. Poza tym, jak wspomniano, nieco inny charakter przyjmuje obecnie struktura podaży samego napoju: gdzieniegdzie pojawiają się piwa mocne, na szeroką skalę wprowadza się radlery (w gospodach coraz częściej oferowane także w wersji beczkowej), upowszechniają się plastikowe butelki. Chociaż zjawiska te nie tworzą podstawowego kanonu czeskiej kultury piwnej, to jednak powinny być potraktowane jako ważny impuls do zgłębienia kwestii przemian dotykających tamtejszy rynek oraz upodobań konsumenckich.

Dyskusję w odniesieniu do kwestii poruszonych powyżej niewątpliwie krępują nieco niedostatki językowe. Manifestują się one - co zapewne nie uszło uwagi czytelnika - tym,

\section{- ...}

28 Z pełną świadomością posłużenia się w tym miejscu złośliwością można zapytać: czy decyzja ta wynika ze strachu, że się menadżerowie poupijają, zrobią awanturę, a na koniec - sobie krzywdę?

29 L. Mazan (współpraca: Z. Hrabica), Polska Praga czyli dlaczego Matejko lubit knedle, Kraków 2007, s. 78. 
że mówiąc o zjawiskach najpowszechniejszych w kontekście gospody, albo trzeba posługiwać się słowami wyróżniającymi się stopniem potoczności na tle stylu właściwego artykułom naukowym (np. „lanie piwa”), albo obficie korzystać z cudzysłowów, albo wreszcie - czego w niniejszym artykule starano się mimo wszystko unikać - pisać o danym zjawisku bez użycia kolokwializmów, za to za pomocą zdań nadmiernie złożonych. Jak można przypuszczać, niedogodności te znajdują odzwierciedlenie w pewnej ostrożności w podejmowaniu tematów, o których trudno się pisze już na poziomie językowym. Tymczasem - zważywszy na niemałą popularność, jaką cieszy się w Polsce czeska kuchnia, piwo i samo państwo - gubi się w ten sposób szansę na głębszą analizę kulturowego fenomenu południowo-zachodnich sąsiadów RP.

Jak sygnalizowano na wstępie, podejmując rozważania osadzone w nurcie komparatystyki narodowej, w zasadzie niemożliwe jest (o czym pisze się np. w literaturze na temat tego rodzaju stereotypów) odcięcie się od własnych zasobów kulturowych. Skutkuje to m.in. tym, że wypowiadając się na temat specyfiki jednej kultury, ujawnia się najważniejsze rysy własnego kanonu. Rodzi się więc pytanie: jak dalece obiektywne są sformułowane wyżej refleksje. Namiastkę odpowiedzi stanowić mogą obserwacje Tima Nollena, amerykańskiego dziennikarza podróżniczego, który w Czechach spędził wiele lat. Pisał on, że Czesi, "jeśli opuszczają dom, to zwykle udają się do piwiarni lub do swej chaty na prowincji. Bujne życie uliczne [...] w Czechach w zasadzie nie występuje". Pomimo zamiłowania do alkoholu, zwłaszcza piwa, nie można powiedzieć, „by Czesi byli narodem alkoholików. Piją w bardzo kulturalny sposób, w towarzystwie, podczas zabawy, a także z umiarkowaniem", choć przekracza ono poziom typowy dla większości innych społeczeństw (chodzi o średnią 162 litry piwa rocznie na każdego mieszkańca Republiki). „Raporty z innych krajów, choćby Rosji, pełne są przykładów dzikiego braku opamiętania w piciu, na co Czesi patrzą z niesmakiem. Picie alkoholu to w końcu czynność społeczna, rządząca się swymi prawami i wymagająca poszanowania pewnych zasad"30. Mając na względzie intersubiektywną sprawdzalność przedstawionych obserwacji, nie od rzeczy będzie także sięgnięcie do publikacji przywołanego już norweskiego dziennikarza, którzy sporządził swoisty słownik czeskiej historii, obyczajowości itd. ${ }^{31}$

Na koniec warto zauważyć, że osobliwości polskiej i czeskiej kultury gospody dadzą się przypuszczalnie wywieść z ogólnej charakterystyki danego kontekstu narodowego. Dla przykładu, Tim Edensor stwierdza, że istnieją dystynktywne sposoby m.in. picia alkoholu, „które uzależnione są zarówno od klasy, etniczności i płci kulturowej, jak i tożsamości narodowej"32. Oznacza to, że być może zasadne byłoby sformułowanie postulatu podjęcia bardziej wnikliwej i mocniej osadzonej w teorii analizy polskich i czeskich nawyków w odniesieniu do szeroko pojmowanych: alkoholu i biesiady. Jakiego typu obserwacje mogłyby potencjalnie być ich rezultatem?

Jako że już na podstawie pobieżnych obserwacji możliwe okazało się ujawnienie kilku rozbieżności pomiędzy nawykami Polaków i Czechów, organizując złożony projekt badawczy przypuszczalnie otrzymalibyśmy nietypowy, a jednak dosyć wartościowy głos w kwestii podobieństwa/odmienności obu narodów. Wstępny katalog tych drugich, który można sporządzić, odwołując się do powyższych refleksji, sugeruje, że w kontekście polsko-czeskim mamy do czynienia z pograniczem ukonstytuowanym nie tylko za sprawą rozdzielającej Polskę i Republikę Czeską granicy państwowej, ale także w warstwie kultury dnia

\section{-....}

30 T. Nollen, Spokojnie to tylko Czechy, Warszawa 2007, s. 41, 44-45.

31 Zob. T.B. Englund, op. cit., passim.

32 T. Edensor, op. cit., s. 119. 
codziennego, a szczególnie obyczajowości biesiadnej. W czeskim odczuciu - jak podpowiada stereotyp - niejednemu Polakowi brakuje ogłady nawet wówczas, gdy nie jest pod wpływem alkoholu, tak więc spożywanie w większej ilości takich napojów omawiane zjawisko tylko wyostrza. Badania przeprowadzone na pograniczu czesko-polskim (Śląsk Cieszyński oraz środkowo-wschodnie obszary województwa libereckiego) pokazują, że konsumpcja alkoholu jest jednym z najmocniej kojarzonych z Polakami atrybutów spośród 21 cech, za pomocą których można stereotypowo opisać człowieka ${ }^{33}$. Wydaje się więc, że istnieją podstawy, aby przyjąć, że zarówno czeski hostinec dla Polaka, jak i polski bar dla Czecha (ale także - szerzej - oba sposoby "obchodzenia się" z alkoholem) stanowią światy dość odmienne od tego, do czego obu przyzwyczaiła ich rodzima rzeczywistość.

\begin{abstract}
Summary
The article aims at outlining the most distinctive features of two elements of the Czech national culture: beer and the places where it is customary consumed. Specifically, the text focuses on characteristics of the position which beer occupies among Czechs, as well as on a social dimension of the "traditional" provincial and village local pubs (specific ambience, a type of service, guests, etc.), which makes the article embedded in the cultural context. A special attention was paid to the restaurants located at the Czech railway stations, too. The analysis was carried out from the Polish perspective, that is why the article includes a range of references to the peculiarities of the Polish culture of drinking. Additionally, the observations were gathered during a number of visits the author paid in the Czech Republic. It all means that the selection of the phenomena presented in the text and the way they were valued might be different if some other national approach were employed here.
\end{abstract}

Keywords: the Czech Republic, beer, pub, culture of drinking

33 M. Dębicki, Stereotypy Czechów wobec Polaków na pograniczu - regionalne zróżnicowanie i determinanty stanu rzeczy, Wrocław 2010, s. 116-132. 